\title{
Application of Artificial Neural Networks Using Bayesian Training Rule in Sales Forecasting for Furniture Industry
}

\section{Primjena umjetnih neuronskih mreža uz pomoć Bayesova pravila učenja u predviđanju prodaje za industriju namještaja}

\author{
Original scientific paper • Izvorni znanstveni rad \\ Received-prispjelo: 26. 1. 2017. \\ Accepted - prihvaćeno: 30. 8. 2017. \\ UDK: $630 * 79$ \\ doi:10.5552/drind.2017.1706
}

\begin{abstract}
Most organizations in manufacturing environments aim to increase their profits and reduce costs against competitive and rapidly changing market conditions. Accuracy of sales forecasting is undoubtedly a successful way to reach the aforementioned goals. At the same time, this enables executives to improve customer satisfaction, reduce lost sales and plan production efficiently. As a growing industry in Turkey, furniture manufacturing has an increased product demand in relation to the recent growth in construction and related industries, increase in urban population and increase in person-level income. Therefore, accurate sales forecasting systems in this industry are more focused on the special and calendar factors, such as consumer confidence index, producer price index, time of the year and number of vacation days. In this paper, an artificial neural network (ANN) based forecasting model is proposed by using MATLAB for processing total monthly sales data of a corporate furniture manufacturer located in the Black Sea region of Turkey. The method is a component of ANN, namely Bayesian regularization. The proposed model is applied to monthly sales figures of a corporate furniture manufacturing company. In conclusion, the results of performance measures show that using the ANN model based on Bayesian rules training is an applicable choice for forecasting of monthly sales of the observed furniture factory.
\end{abstract}

Keywords: artificial neural networks; Bayesian rules training; sales forecasting; furniture manufacturing

SAŽETAK • Cilj većine proizvodnih organizacija jest povećanje dobiti i smanjenje troškova u skladu s konkurentnim i promjenjivim tržišnim uvjetima. Točnost predviđanja prodaje nesumnjivo je uspješan način postizanja navedenih ciljeva. Istodobno, to povećava zadovoljstvo korisnika, učinkovito smanjuje izgubljenu prodaju i omogućuje bolje planiranje proizvodnje. U proizvodnji namještaja, industriji koja se u Turskoj sve jače razvija, bilježi se povećana potražnju proizvoda, u skladu s nedavnim rastom građevinskih i srodnih industrija, s povećanjem broja urbanog stanovništva i s rastom osobnih prihoda. Stoga precizni sustavi predviđanja prodaje u industriji namještaja više pozornosti usmjeravaju na posebne i kalendarske čimbenike poput indeksa povjerenja potrošača, indeksa proizvođačkih cijena, doba godine i broja dana odmora u godini. U ovom je radu predložen model predviđanja

\footnotetext{
${ }^{1}$ Author is assistant professor at Munzur University, Engineering Faculty, Department of Mechanical Engineering, Tunceli, Turkey. ${ }^{2,3}$ Authors are assistant professors at Munzur University, Engineering Faculty, Department of Industrial Engineering, Tunceli, Turkey.

${ }^{1}$ Autor je docent Munzur sveučilišta, Fakultet inženjerstva, Strojarski odjel, Tunceli, Turska. ${ }^{2}$ Autori su docenti Munzur sveučilišta, Fakultet inženjerstva, Odjel industrijskog inženjerstva, Tunceli, Turska.
} 
na temelju umjetne neuronske mreže (ANN) uz pomoć MATLAB-a za obradu podataka ukupne mjesečne prodaje proizvođača uredskog namještaja koji se nalazi u Crnomorskoj regiji u Turskoj. Metoda je komponenta ANN-a, tj. Bayesova regulacija. Predloženi se model primjenjuje na podatke o mjesečnoj prodaji tvrtke za proizvodnju uredskog namještaja. Zaključno, rezultati mjerenja uspješnosti pokazuju da je primjena ANN modela utemeljenoga na Bayesovim pravilima dobar izbor za prognoziranje mjesečne prodaje promatrane tvornice namještaja.

Ključne riječi: umjetne neuronske mreže, Bayesova pravila učenja, predviđanje prodaje, proizvodnja namještaja

\section{INTRODUCTION}

\section{UVOD}

Forecasting is a methodology for estimating future characteristics of a business or operation (Gahirwal and Vijayalakshmi, 2013). Forecasts gain importance for short-term, mid-term and long-term decisions. In the literature, forecasting is applied to several business areas such as demand forecasting and sales forecasting (Yip et al., 1997; Alon et al., 2001; Kuo et al., 2002; Mahbub et al., 2013). Sales forecasting of a business is described as a prediction depending on past sales performance and an analysis of expected market conditions (Gahirwal and Vijayalakshmi, 2013), and it is considered the starting point for the elaboration of business plans (Fabianová, 2016). Many management decisions are often influenced by the current market situation (Gahirwal and Vijayalakshmi, 2013). Since the firms face dynamic complexities of internal and external factors, many apply qualitative forecasting techniques (Luxhøj et al., 1996). However, these techniques are mostly inadequate compared to quantitative forecasting models with their structure and extrapolation capability, and forecasting inaccuracies typically negatively affect the mechanism of production planning. Accuracy of forecasting affects readiness of the business to be flexible in responding to market demand, its future costs and benefits (Fabianová, 2016). Mahbub et al., (2013) highlight some inaccuracies and errors in demand forecasting as follows: difficulty in identifying the real factors that are actually influencing the demand, uncertainty in the demand of the products, non-availability of the actual demand data of the earlier demand periods. To this end, this study presents the application of a quantitative forecasting tool Bayesian rules training algorithm in Artificial Neural Networks (ANNs) for forecasting total monthly sales of a corporate furniture manufacturing company located in the Black Sea region of Turkey.

Recently, demand for furniture products have rapidly increased in Turkey in relation to the recent growth in construction and related industries, increase in urban population and increase in person-level income (Hazır et al., 2015; Internet 1). Strengths of the industry, such as geographic location, trend of development in the sector, performance of the sector in the recent years, high labor potential, increasing technology transfer in the sector, increase in the number of firms producing modern and technological production, furniture production network/ potential, increase in export activities for target markets, broad distribution network, material and product variety, prompt manufacturers to efficiently control and deter- mine sales and demand (Turkey Furniture Products Council Industry Report, 2013). In order to do this, many firms prefer more sophisticated statistical models and accurate forecasting tools. ANNs are such tools that are successfully applied for forecasting sales, demand and predicting situations in a number of fields. Therefore, sales data of a corporate furniture manufacturer in Trabzon, Turkey from January 2009 to December 2015 were studied.

The rest of the paper is organized as follows: Section 2 gives a brief summary of ANNs used in this research; Section 3 provides the application, which includes data used, accuracy results of developed models and discussion. Finally, the conclusions are given in Section 4.

\section{ARTIFICIAL NEURAL NETWORKS (ANNs)} 2. UMJETNE NEURONSKE MREŽE (ANNS)

ANNs are machine learning algorithms, which aim to solve the computational processes in specific areas by using a large number of interconnected processing elements (Gul and Guneri, 2015; Akkoyunlu et al., 2015; Gul and Guneri, 2016a; 2016b; Yapıcı et al., 2015). They are mainly used for prediction, clustering, classification, and alerting to abnormal patterns (Efendigil et al., 2009; Pusat et al., 2016). An ANN model, which is formed of $n$ layers, presents a different number of computational elements that function like biological neurons and intensive connections between these computational elements among layers. The computational elements used in various ANN models are called artificial neurons (Guneri and Gumus, 2008; 2009). In Efendigil et al. (2009), the model flow of an artificial neuron is presented as in Figure 1.

In Figure $1, x_{1}, x_{2}, \ldots, x_{p}$ are the input signals; $w_{k 1}, w_{k 2}, \ldots, w_{k p}$ are the weights of neuron $k$, and, $u_{k}$ is the linear combiner output, while $\theta_{k}$ denotes the threshold. Furthermore, $\Phi()$ is the activation function; and $y_{k}$ is the output of the neuron. The first layer, called the "input" layer, and the last layer, called the "output" layer, are used to get information from inside and outside the network, respectively. The middle layers, generally called "hidden" layers, are essential to the network as they enable converting certain input patterns into appropriate output patterns (Akkoyunlu et al., 2015; Somoza and Somoza, 1993). The flow of information is passed through the network by linear connections and linear or nonlinear transformations. Learning of the ANNs can be categorized into two distinct groups: supervised learning and unsupervised learning. The error between the actual output value and the pre- 


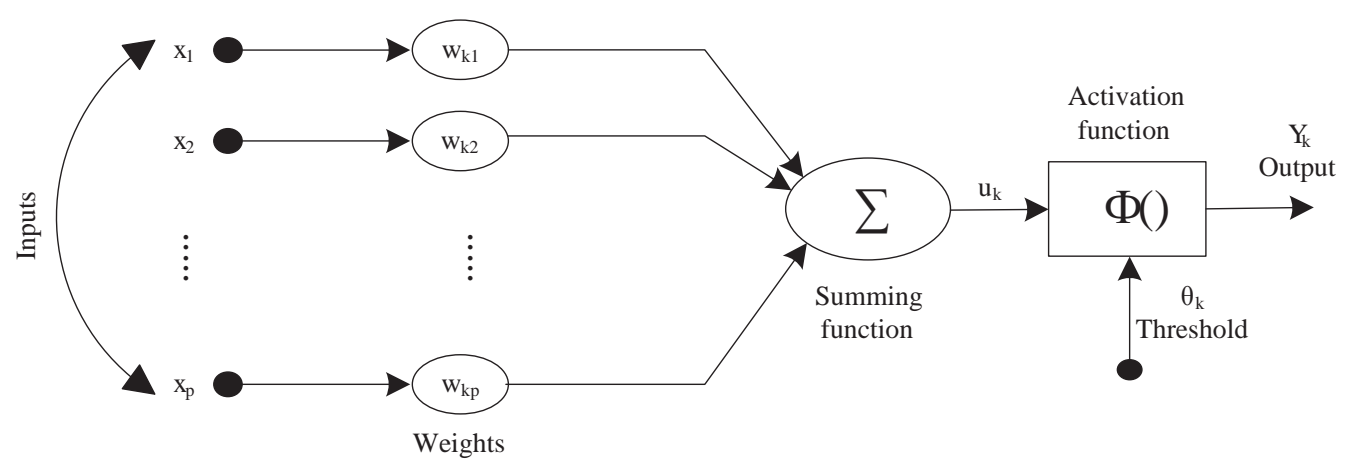

Figure 1 Flow chart of an artificial neuron (Adapted from Efendigil et al., 2009)

Slika 1. Dijagram toka jednoga umjetnog neurona (adaptirano iz Efendigil et al., 2009.)

dicted output value is computed. Then a minimization procedure is used to adjust the weights between two connection layers, i.e. for back propagation model starting backwards from the output layer to input layer. There are many minimization procedures based on different optimization algorithms, such as Quasi-Newton, and Levenberg-Marquardt, gradient descent and conjugate gradient methods. ANN models have a practical problem in network architecture (number of hidden layers and units in each layer) and network properties (error and activation functions). The design of hidden layers is dependent on the selected learning algorithm (Kröse et al., 1993). The more layers and neurons, the more complex dependencies the network can model. According to the study of Efendigil et al. (2009), the number of hidden layer nodes can be up to (1) $2 n+1$ (where $n$ is the number of nodes in the input layer), (2) $75 \%$ of the quantity of input parameters, or (3) $50 \%$ of the quantity of input and output parameters. Another important property of an ANN model is the activation function of the hidden layer. The software used in the current research has the following functions:

- Linear: This function produces its input as its output or, in other words, it passes the activation level directly as the output. Its output range is $(-\infty, \infty)$.

- Logistic: This function has a sigmoid curve and is calculated as in Eq. (1):

$$
F(x)=1 /\left(1+e^{-x}\right)
$$

Its output range is [0..1]. This function is used most often in various practical applications.

- Hyperbolic tangent: This function also has a sigmoid curve and is calculated as in Eq. (2):

$$
F(x)=\left(e^{x}-e^{-x}\right) /\left(e^{x}+e^{-x}\right)
$$

Its output range is [-1..1]. Empirically, it is often found that this function performs better than the Logistic function.

In ANNs, some controllable factors are available in order to aid the learning of the selected algorithm such as Learning Rate and Momentum. They are control parameters used by several learning algorithms, which affect the changing of weights. The higher learning rates cause higher weight changes during each iteration. The greater the momentum, the more the current weight change is affected by the weight change that took place during the previous iteration.
To measure the performance of ANN models, mean squared error (MSE), network error (average train error and average test error), absolute relative error (ARE), mean absolute percentage error (MAPE) and R-squared $\left(R^{2}\right)$ can be used. $R^{2}, M S E$ and MAPE are defined as in Eqs. (3)-(5).

$$
R^{2}=1-\frac{S S_{\text {residuals }}}{S S_{\text {total }}}
$$

where $S S_{\text {total }}$ refers to the total sum of squares (proportional to the variance of data), and $S_{\text {residuals }}$ indicate the sum of squares of residuals, also called the residual sum of squares.

$$
\begin{gathered}
M S E=\frac{1}{n} \sum_{i=1}^{n}\left(f_{i}-y_{i}\right)^{2} \\
M A P E=\frac{100}{n} \sum_{i=1}^{n}\left|\frac{y_{i}-f_{i}}{y_{i}}\right|
\end{gathered}
$$

Where $f_{i}$ is the vector of $\mathrm{n}$ forecasting, and $y_{i}$ is the vector of actual values.

\subsection{Bayesian rules training in ANN}

2.1. Bayesovo pravilo učenja u ANN-u

Bayesian networks are robust approach for making inferences and drawing conclusions based on available information (Jensen, 1996; Doğan and Aydin, 2011). The gradient descent method is used in the back propagation neural network as supervised learning to reduce a chosen error function. The weights of input are changed in the supervised learning algorithm to decrease the chosen error function to optimize the network for use with unknown samples. A major problem for these techniques is the potential for overfitting an overtraining, which leads to a fitting of the noise and a loss of network generalization ability (Ticknor, 2013). Bayesian regularization is developed to convert nonlinear systems into "well posed" problems to reduce the potential for overfitting (Burden and Winkler, 2008; MacKay, 1992). In general, the training step is aimed at reducing the error function of the model output and target value. Bayesian regularization adds an additional term to Eq. (6):

$$
F=\beta E_{D}+\alpha E_{W}
$$

Where $\mathrm{F}$ is the objective function, $E_{D}$ is the sum of squared errors, $E_{w}$ is the sum of squared network weights, and $\alpha$ and $\beta$ are objective function parameters 
(MacKay, 1992; Ticknor, 2013). The random variables are taken as weights and hence their density function is presented with respect to the Bayes rules (Foresee and Hagan, 1997) as in Eq. (7):

$P=(D \mid w, \alpha, \beta, M)=\frac{P(D \mid w, \beta, M) P(D \mid w, \alpha, M)}{P=(D \mid \alpha, \beta, M)}$

Where $w$ is the vector of network weights, $D$ represents the data vector, and $M$ is the neural network model used. In Bayesian regularized networks, very complex models are penalized as redundant relation, where weights are effectively driven to zero. The network will be used with constant weights as the network grows (Burden and Winkler, 2008).

\section{APPLICATION}

\section{PRIMJENA}

\subsection{Data}

3.1. Podatci

The data used in this paper were derived from one of the biggest furniture factory in the Black Sea region of Turkey. The factory in Trabzon Organized industry, located in a closed area of $120,000 \mathrm{~m}^{2}$, produces bedrooms, dining rooms, sitting groups, teen rooms and armchairs. The data set contains monthly sales figures of these products in the period 2009 to 2015. The time series plot is given in Figure 2, showing monthly sales figures of products.

The company's product range consists of different models for dining rooms, sitting groups, teen rooms, bedrooms and armchairs. There are 14 models of dining rooms, 14 models of bedrooms, 14 models of sitting rooms and 6 models of teen rooms. Every model consists of different parts. For example, the teen room consists of a bookcase, desk, laundry, nightstand, bedstead and wardrobe and these parts must be equal in every model. In other words, when one model of teen room is sold, one bookcase, one desk, one laundry, one nightstand, one bedstead and one wardrobe of the same model will also be sold (Eq. 8). There is no a special model type for the armchair. It is sold as single.

$\forall\left(X_{i, j}=X_{i+1, j}=X_{i+2, j}=X_{i+3, j}=X_{i+4, j}=X_{i+5, j}\right)(8)$

Where

$X_{i}$ - size of parts

$j$ - number of produced models ( $j=1$ to 48 )

In order to forecast sales value of the furniture company, four parameters were used as input parameters of ANN model. One of them is consumer confidence index (CCI). CCI is an aggregate of four subindices. Two of them are based on expectations regarding household finances, while the other two are based on expectations about economy-wide developments (Jansen and Niek, 2003). The second input parameter is the producer price index (PPI). PPI is an aggregate of over 1,500 components. Each component is a monthly index of the national average price for a producer good. The price pertains to the first transaction after production. This is a transaction between firms rather than between businesses and consumers (Peltzman, 2000). Other input parameters are the number of vacation days in Turkey and time of the year. The number of vacation days in our data set is shown in Table 1 .

The output parameters are monthly sales of teen rooms, bedrooms, dining rooms, sitting groups and armchairs. Inputs and outputs for proposed ANN model are shown in Figure 3.

Parameters of the inputs and outputs were collected for 84 months from January 2009 to December 2015 from the furniture company. Descriptive statistics of variables are presented in Table 2. The values of CCI and PPI are ratios that have a mean of 72.85 and 209.2, respectively. The mean number of vacation days in the studied data set is 9.45 per month. The reason of considering this input variable in our proposed ANN

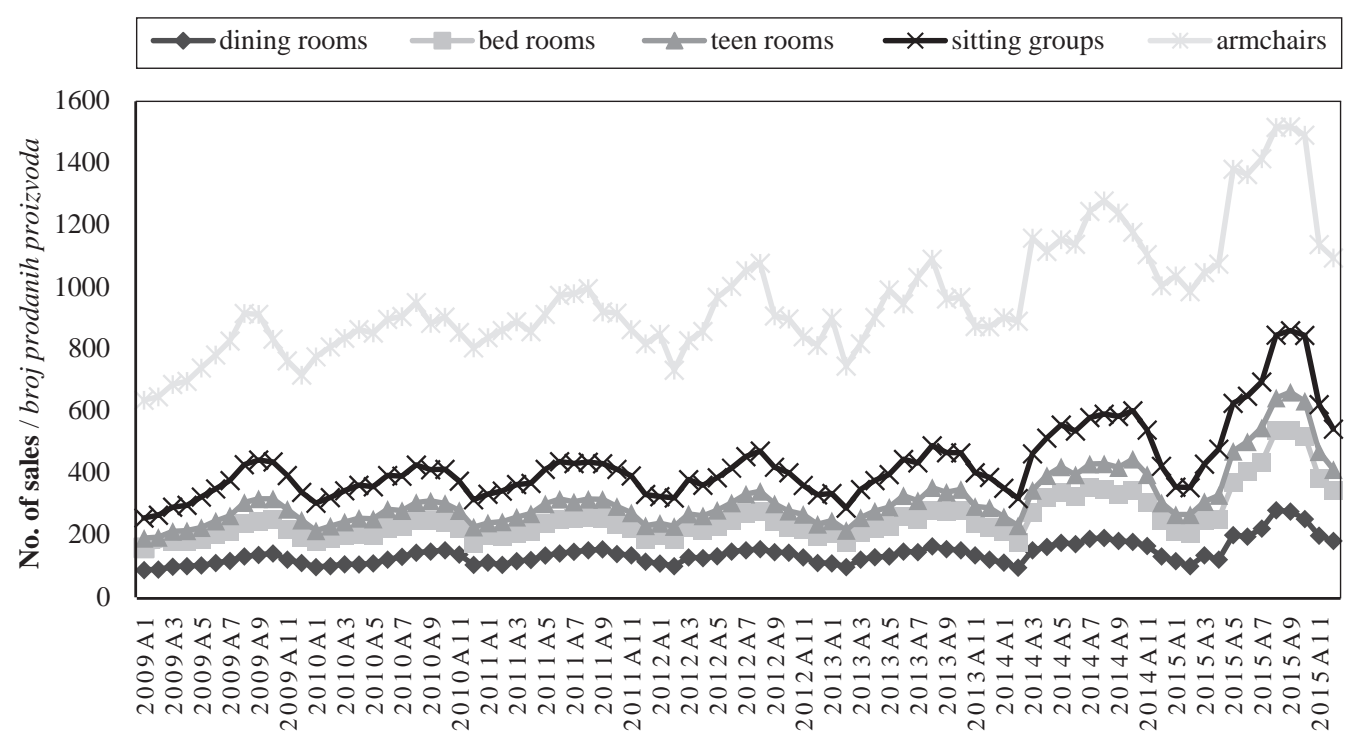

Time, month, year / vrijeme, mjesec, godina

Figure 2 Sales figures of products

Slika 2. Podatci o prodaji proizvoda 
Table 1 Number of vacation days

Tablica 1. Broj dana odmora

\begin{tabular}{|c|c|c|c|c|c|c|c|}
\hline & \multicolumn{7}{|c|}{ Year / Godina } \\
\hline $\begin{array}{c}\text { Month } \\
\text { Mjesec }\end{array}$ & $\mathbf{2 0 0 9}$ & $\mathbf{2 0 1 0}$ & $\mathbf{2 0 1 1}$ & $\mathbf{2 0 1 2}$ & $\mathbf{2 0 1 3}$ & $\mathbf{2 0 1 4}$ & $\mathbf{2 0 1 5}$ \\
\hline 1 & 10 & 11 & 10 & 9 & 9 & 9 & 10 \\
\hline 2 & 8 & 8 & 8 & 8 & 8 & 8 & 8 \\
\hline 3 & 9 & 8 & 8 & 9 & 10 & 10 & 9 \\
\hline 4 & 9 & 9 & 9 & 10 & 9 & 9 & 9 \\
\hline 5 & 12 & 11 & 10 & 9 & 9 & 11 & 12 \\
\hline 6 & 8 & 8 & 8 & 9 & 10 & 9 & 8 \\
\hline 7 & 8 & 9 & 10 & 9 & 8 & 11 & 9 \\
\hline 8 & 10 & 10 & 10 & 11 & 12 & 10 & 10 \\
\hline 9 & 10 & 10 & 9 & 10 & 9 & 8 & 10 \\
\hline 10 & 10 & 11 & 10 & 11 & 13 & 11 & 10 \\
\hline 11 & 11 & 12 & 11 & 8 & 9 & 10 & 9 \\
\hline 12 & 8 & 8 & 9 & 10 & 9 & 8 & 8 \\
\hline
\end{tabular}

Table 2 Descriptive statistics of variables

Tablica 2. Deskriptivna statistika varijabli

\begin{tabular}{|l|c|l|c|c|c|c|}
\hline Parameters / Parametri & $\begin{array}{c}\text { Unit } \\
\text { Jedinica }\end{array}$ & $\begin{array}{c}\text { Type } \\
\text { Vrsta }\end{array}$ & $\begin{array}{c}\text { Mean } \\
\text { Srednja vrijednost }\end{array}$ & $\begin{array}{c}\text { Variance } \\
\text { Varijanca }\end{array}$ & $\begin{array}{c}\text { Max } \\
\text { Maksimum }\end{array}$ & $\begin{array}{c}\text { Min } \\
\text { Minimum }\end{array}$ \\
\hline CCI & Ratio / omjer & Input /ulaz & 72.85 & 32.4 & 83.19 & 58.33 \\
\hline PPI & Ratio / omjer & Input /ulaz & 209.2 & 1052.13 & 269.5 & 160.4 \\
\hline $\begin{array}{l}\text { Number of vacation days } \\
\text { broj dana godišnjeg odmora }\end{array}$ & $\begin{array}{c}\text { Numerical } \\
\text { numerički }\end{array}$ & Input /ulaz & 9.45 & 1.41 & 13 & 8 \\
\hline $\begin{array}{l}\text { Teen room sales } \\
\text { prodaja tinejdžerskih soba }\end{array}$ & $\begin{array}{l}\text { Numerical } \\
\text { numerički }\end{array}$ & Output / izlaz & 60.44 & 362.48 & 122 & 29 \\
\hline $\begin{array}{l}\text { Bedroom sales } \\
\text { prodaja spavaćih soba }\end{array}$ & $\begin{array}{l}\text { Numerical } \\
\text { numerički }\end{array}$ & Output / izlaz & 114.2 & 1706.66 & 268 & 70 \\
\hline $\begin{array}{l}\text { Dining room sales } \\
\text { prodaja blagovaonica }\end{array}$ & $\begin{array}{l}\text { Numerical } \\
\text { numerički }\end{array}$ & Output / izlaz & 140.4 & 1440.45 & 281 & 88 \\
\hline $\begin{array}{l}\text { Sitting groups sales } \\
\text { prodaja namještaja za sjedenje }\end{array}$ & $\begin{array}{l}\text { Numerical } \\
\text { numerički }\end{array}$ & Output / izlaz & 115.2 & 747.96 & 212 & 65 \\
\hline $\begin{array}{l}\text { Armchair sales } \\
\text { prodaja naslonjača }\end{array}$ & $\begin{array}{l}\text { Numerical } \\
\text { numerički }\end{array}$ & Output / izlaz & 531 & 7330.78 & 755 & 370 \\
\hline
\end{tabular}

model stems from the fact that, according to decision makers in furniture industry, the number of sales increases in vacation days. The mean number of teen

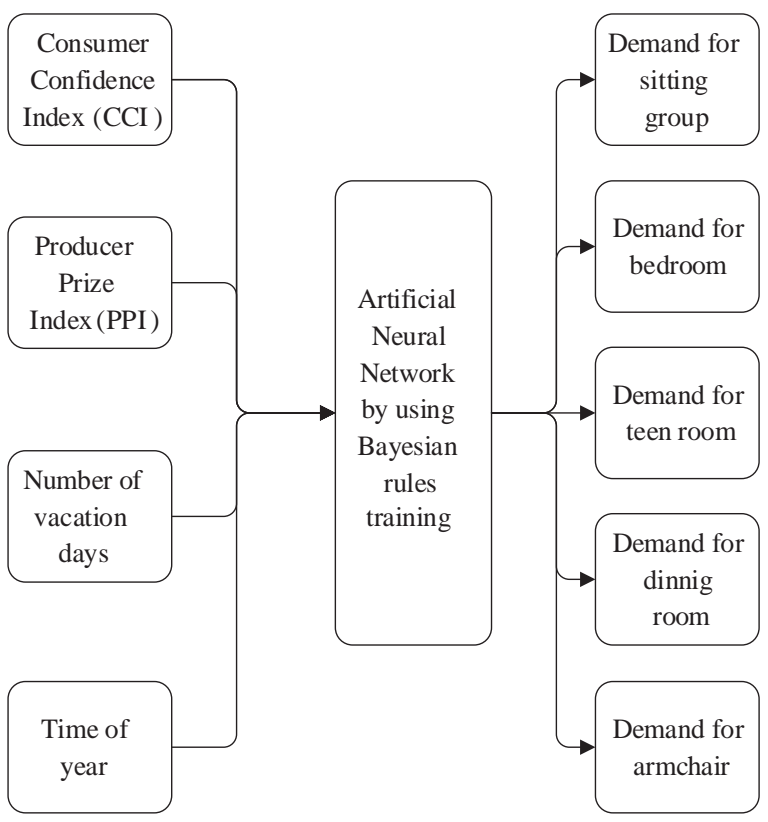

Figure 3 Proposed ANN model

Slika 3. Predloženi model ANN-a room sales, bedroom sales, dining room sales, sitting group sales and armchair sales vary from 60.44 to 531 .

\section{RESULTS AND DISCUSSION 4. REZULTATI I RASPRAVA}

The main aim of this study was to forecast the monthly sales of a corporate furniture manufacturing company located in the Black Sea region of Turkey. To achieve this aim, an ANN-based approach was proposed. First, the data detailed above were put together. The model included 84 data points for each output variable. This process was followed by data partition and normalization by min-max normalization method. A training and testing model based on ANN was then employed, after determining the design architecture and network properties. A tangent sigmoid (tansig) transfer function and linear (purelin) transfer function were applied in hidden and output layer, respectively. Three layers, including input, hidden and output layers, were formed in the model as presented in Figure 4. While "15" represents the number of inputs in the input layer, "11" shows the number of neurons with the best accuracy value in the hidden layer. " 5 " shows the number of outputs in the output layer. The accurateness of the model is directly re- 


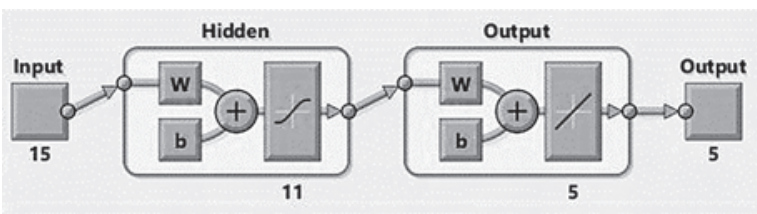

Figure 4 Structure of applied ANN network

Slika 4. Struktura primijenjene mreže ANN-a

lated to the number of neurons in the hidden layer. The performance indicators of $\mathrm{R}^{2}$ and MSE were used to evaluate the accurateness of the method. Finally, the best network was applied reflecting the variability.

Commercial software, MATLAB, was used throughout the study. The proposed model was run for a different number of hidden layer neurons. The system matrix to be tested was selected as $4 \times 84$ input matrix with 1 x84 output matrix. The number of hidden neurons varied from 1 to 30 for evaluating the performance of the model with different neuron numbers. The performance results of 30 experiments with a different number of neurons are presented in Table 3. After the data were loaded into the software, it randomly selected 70:15:15 ratios for training, validation and testing. The experiments were run with Bayesian rules training. The best networks and their performance measure are indicated in bold in Table 3. While $R^{2}$ value is obtained as 0.982961154 and 0.724966567 for training and testing, the MSE is obtained as 0.000644576 and 0.0101874 for training and testing, respectively.

The validation performance and regression plot of the best network are presented in Figure 5. The validation performance plot demonstrates that MSE becomes minimum at epoch 426 and no significant over fitting occurs when the best validation performance is obtained. The regression plot shows network output and targets for training, testing and they are all almost close because the coefficient of determination is almost equal to 1 (Figure 6).

The plots related to the comparison of the actual and forecasted values for the model are made by the software as shown in Figures 7-11. The results show that using the ANN model based on Bayesian rules training is an applicable choice for forecasting monthly sales of the observed furniture factory. The MAPE value of the sitting product group is calculated as $5.223 \%$, which means that a reasonable result is obtained (Çelik et al., 2016). On the other hand, MAPE values are also calculated for the sales forecasting of bedroom, teen room, dining room, and armchair as $5.951 \%, 5.954 \%$, $3.588 \%$, and $3.057 \%$, respectively.

Table 3 Experiments with a different number of neurons

Tablica 3. Eksperimenti s različitim brojem neurona

\begin{tabular}{|c|c|c|c|c|}
\hline \multirow{2}{*}{$\begin{array}{l}\text { Number of Neurons } \\
\text { Broj neurona }\end{array}$} & \multicolumn{2}{|c|}{$R^{2}$} & \multicolumn{2}{|c|}{ MSE } \\
\hline & $\begin{array}{l}\text { Training } \\
\text { Učenje }\end{array}$ & $\begin{array}{c}\text { Testing } \\
\text { Provjera }\end{array}$ & $\begin{array}{l}\text { Training } \\
\text { Učenje }\end{array}$ & $\begin{array}{l}\text { Testing } \\
\text { Provjera }\end{array}$ \\
\hline 1 & 0.752129501 & 0.792244187 & 0.009006000 & 0.019161000 \\
\hline 2 & 0.875669236 & 0.636392299 & 0.005788060 & 0.015446200 \\
\hline 3 & 0.890656513 & 0.808130880 & 0.004532460 & 0.015282300 \\
\hline 4 & 0.915598283 & 0.826439174 & 0.000107210 & 0.024810950 \\
\hline 5 & 0.922485333 & 0.815716049 & 0.003227050 & 0.013012000 \\
\hline 6 & 0.949157217 & 0.529062753 & 0.002550710 & 0.011339400 \\
\hline 7 & 0.961754837 & 0.680398969 & 0.001806460 & 0.016721700 \\
\hline 8 & 0.970745150 & 0.637928080 & 0.001386840 & 0.016071000 \\
\hline 9 & 0.977169813 & 0.516630313 & 0.001006140 & 0.031910500 \\
\hline 10 & 0.971436928 & 0.710347238 & 0.001001700 & 0.029709000 \\
\hline 11 & 0.982961154 & 0.724966567 & 0.000644576 & 0.010187400 \\
\hline 12 & 0.985080070 & 0.590827434 & 0.000570310 & 0.041409100 \\
\hline 13 & 0.914146332 & 0.660912091 & 0.000411074 & 0.016425200 \\
\hline 14 & 0.991603699 & 0.465867677 & 0.000414008 & 0.051115500 \\
\hline 15 & 0.991964209 & 0.595196820 & 0.000389077 & 0.015593300 \\
\hline 16 & 0.995724580 & 0.593357468 & 0.000201961 & 0.017802300 \\
\hline 17 & 0.974326926 & 0.547964141 & 0.000125438 & 0.015422800 \\
\hline 18 & 0.998504560 & 0.382565753 & 0.000074672 & 0.019955900 \\
\hline 19 & 0.999558049 & 0.497965915 & 0.000022625 & 0.031717900 \\
\hline 20 & 0.999998000 & 0.531887242 & 0.000000010 & 0.283021000 \\
\hline 21 & 0.999998000 & 0.660001884 & 0.000000000 & 0.019164000 \\
\hline 22 & 0.999998000 & 0.269372418 & 0.000000000 & 0.018399500 \\
\hline 23 & 0.999998000 & 0.515697771 & 0.000000000 & 0.042244500 \\
\hline 24 & 0.999998000 & 0.317472522 & 0.000000000 & 0.062623300 \\
\hline 25 & 0.999998000 & 0.673871885 & 0.000000000 & 0.037031500 \\
\hline 26 & 0.999998000 & 0.594982365 & 0.000000000 & 0.029209500 \\
\hline 27 & 0.986247610 & 0.591359462 & 0.000056606 & 0.032884600 \\
\hline 28 & 0.999998000 & 0.481624896 & 0.000000002 & 0.025859000 \\
\hline 29 & 0.999998000 & 0.660609703 & 0.000000000 & 0.025427500 \\
\hline 30 & 0.999998000 & 0.277704759 & 0.000000000 & 0.037270000 \\
\hline
\end{tabular}


.... Yucesan, Gul, Celik: Application of Artificial Neural Networks Using Bayesian Training...

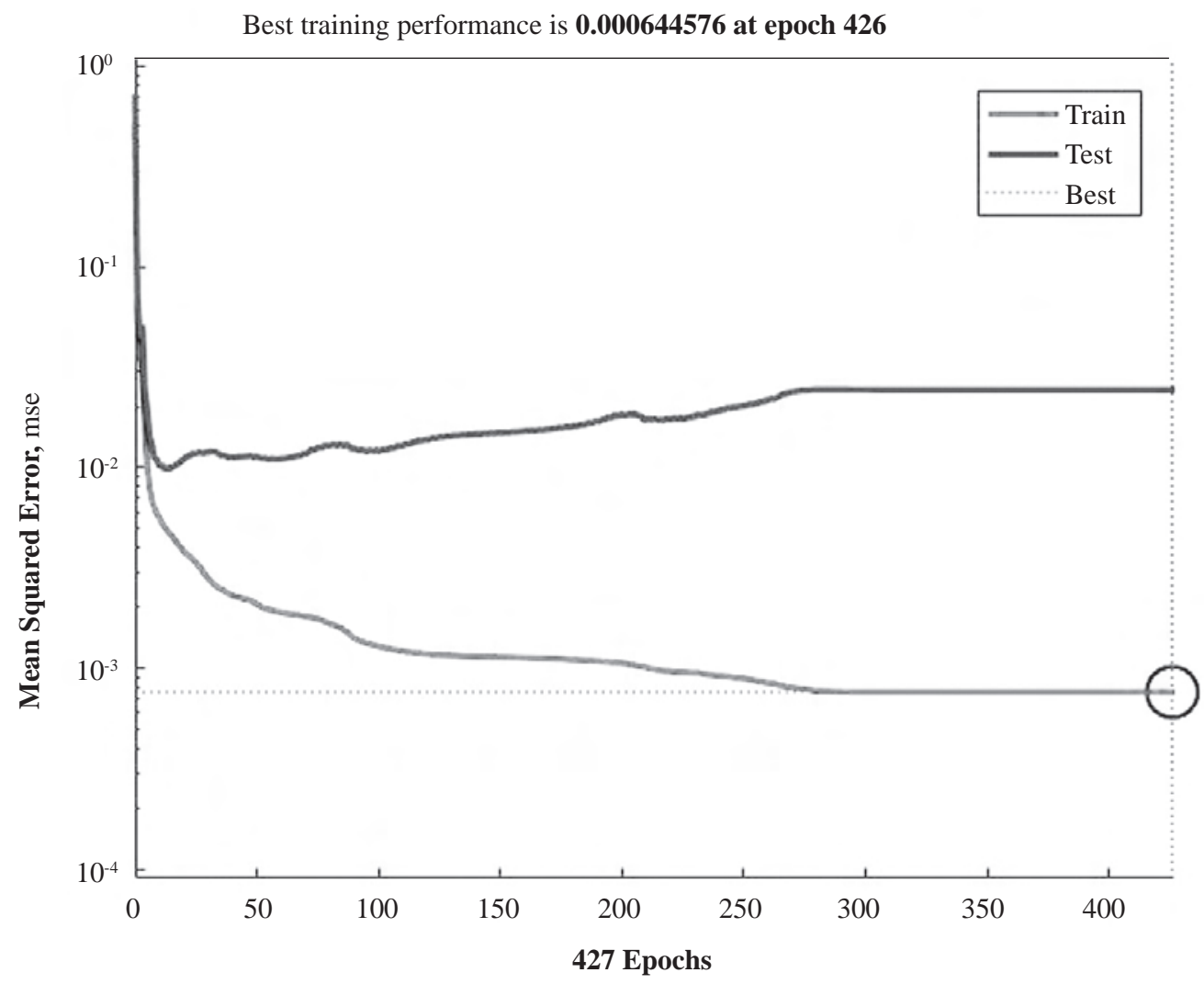

Figure 5 Validation performance

Slika 5. Vrednovanje izvršenja
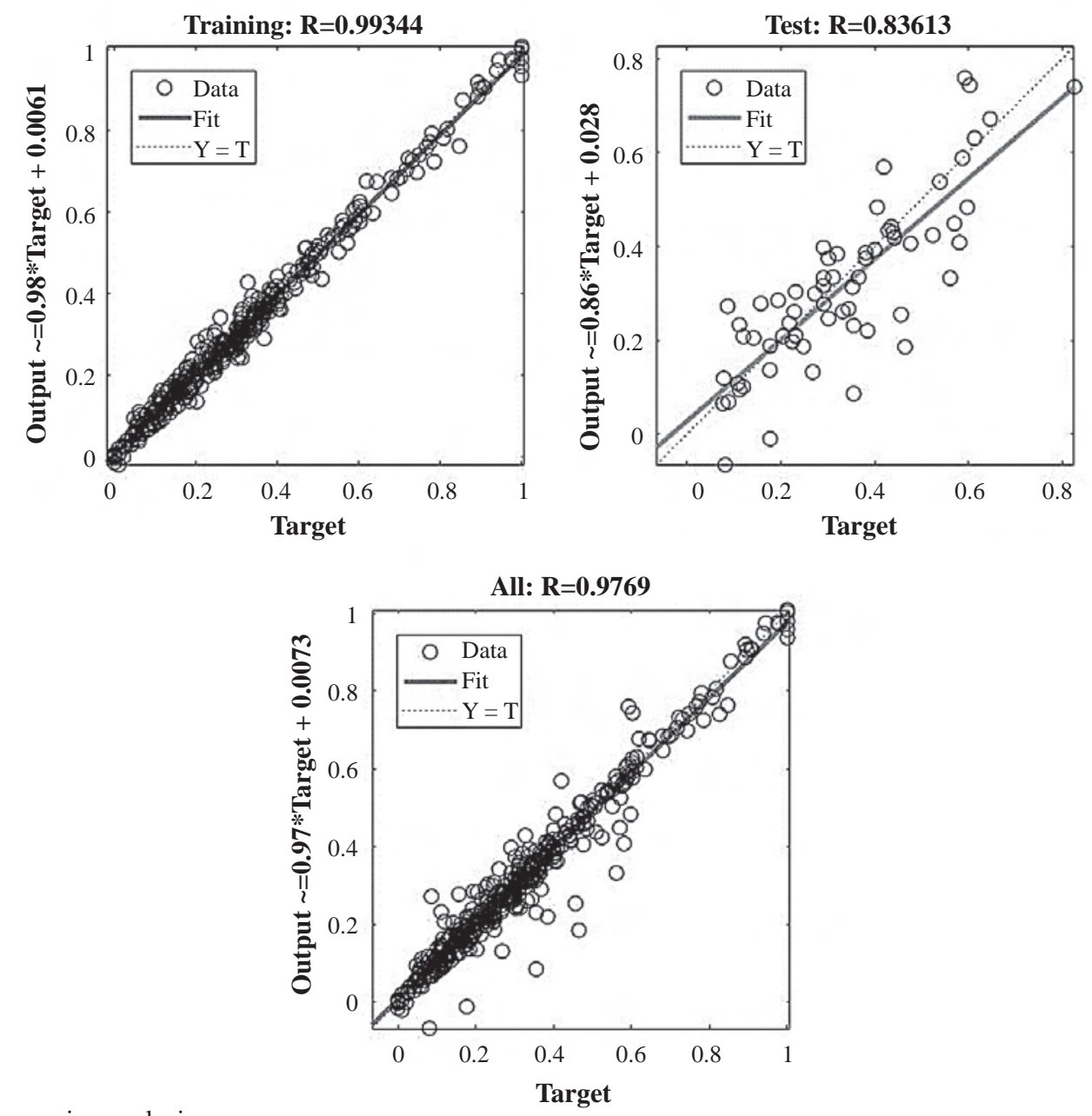

Figure 6 Regression analysis

Slika 6. Regresijska analiza 


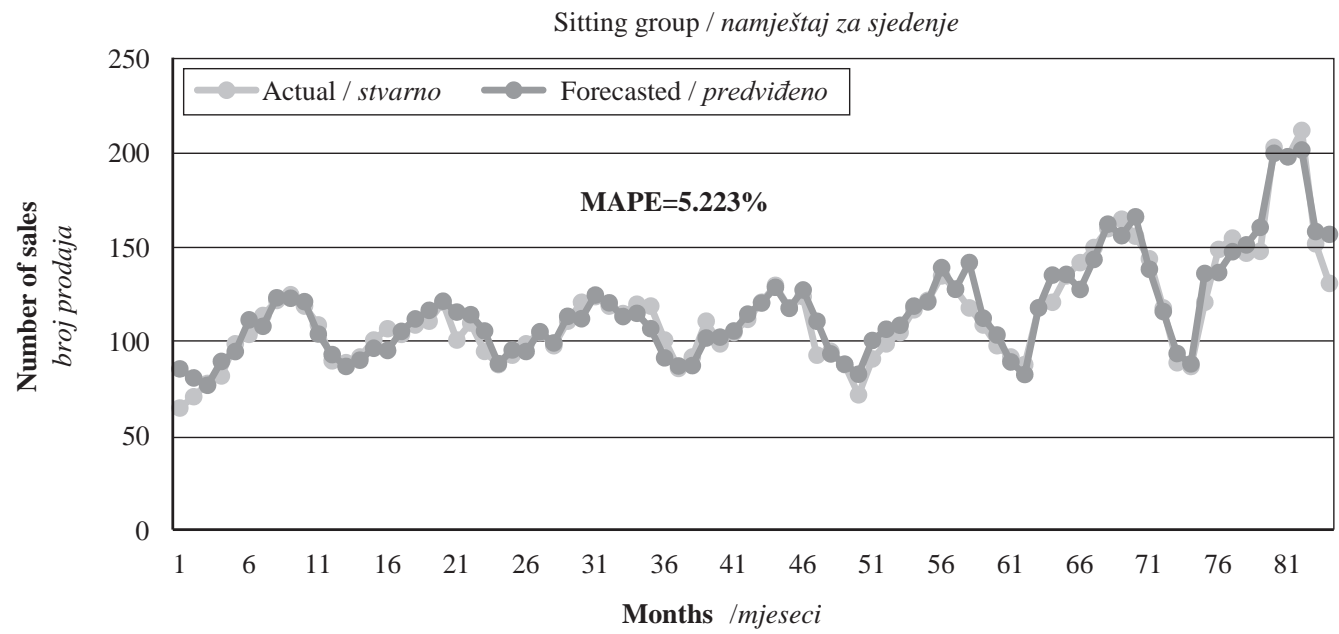

Figure 7 Comparison of actual values and forecasted output values for sitting group product Slika 7. Usporedba stvarnih i predviđenih vrijednosti prodaje namještaja za sjedenje

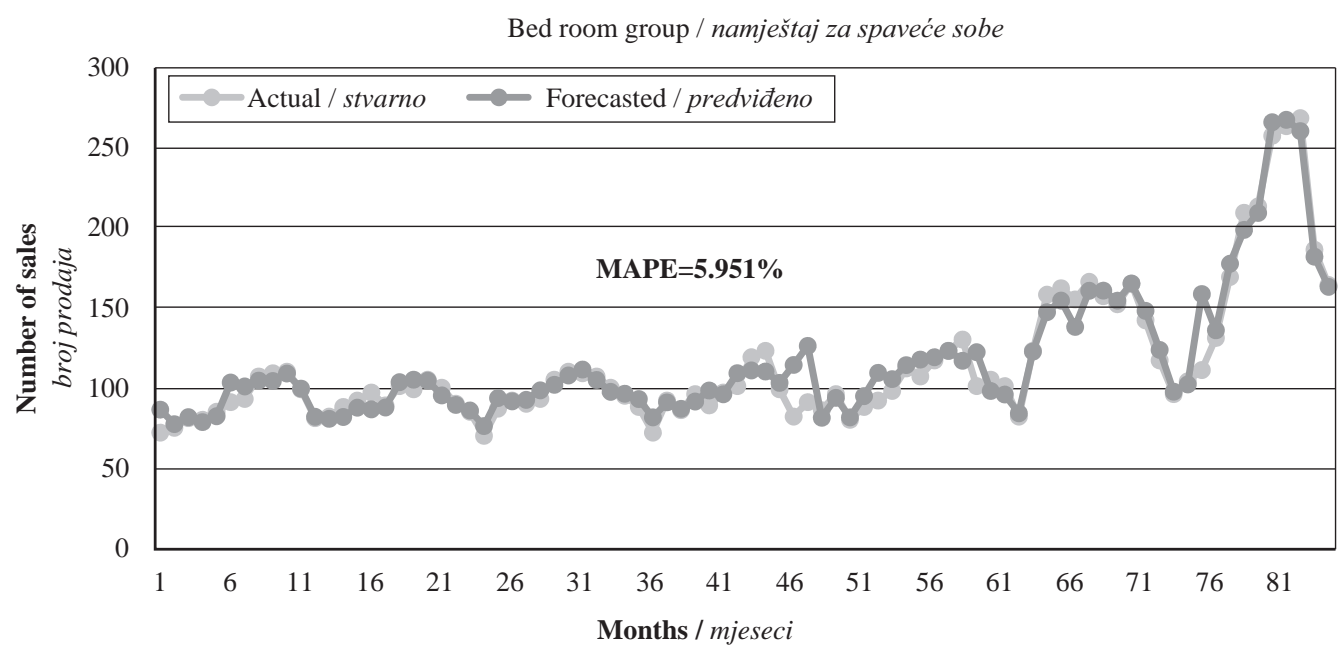

Figure 8 Comparison of actual values and forecasted output values for bedroom product Slika 8. Usporedba stvarnih i predviđenih vrijednosti prodaje namještaja za spavaće sobe

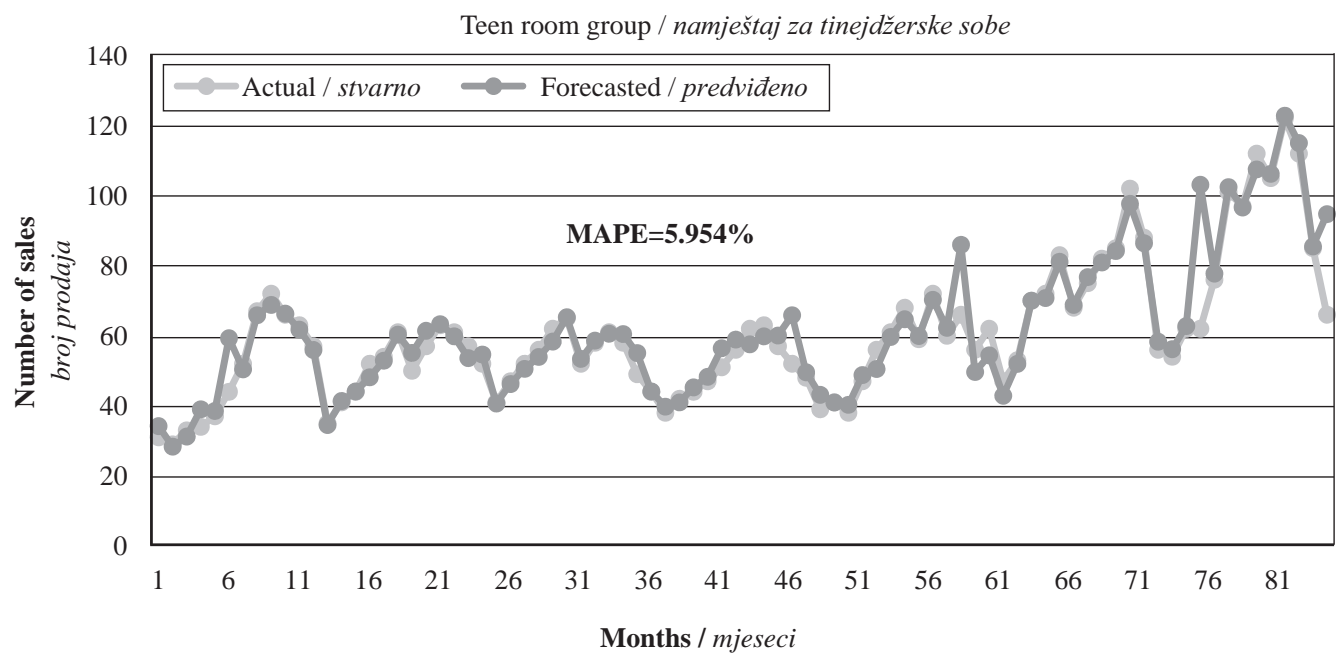

Figure 9 Comparison of actual values and forecasted output values for teen room product

Slika 9. Usporedba stvarnih i predviđenih vrijednosti prodaje namještaja za tinejdžerske sobe 


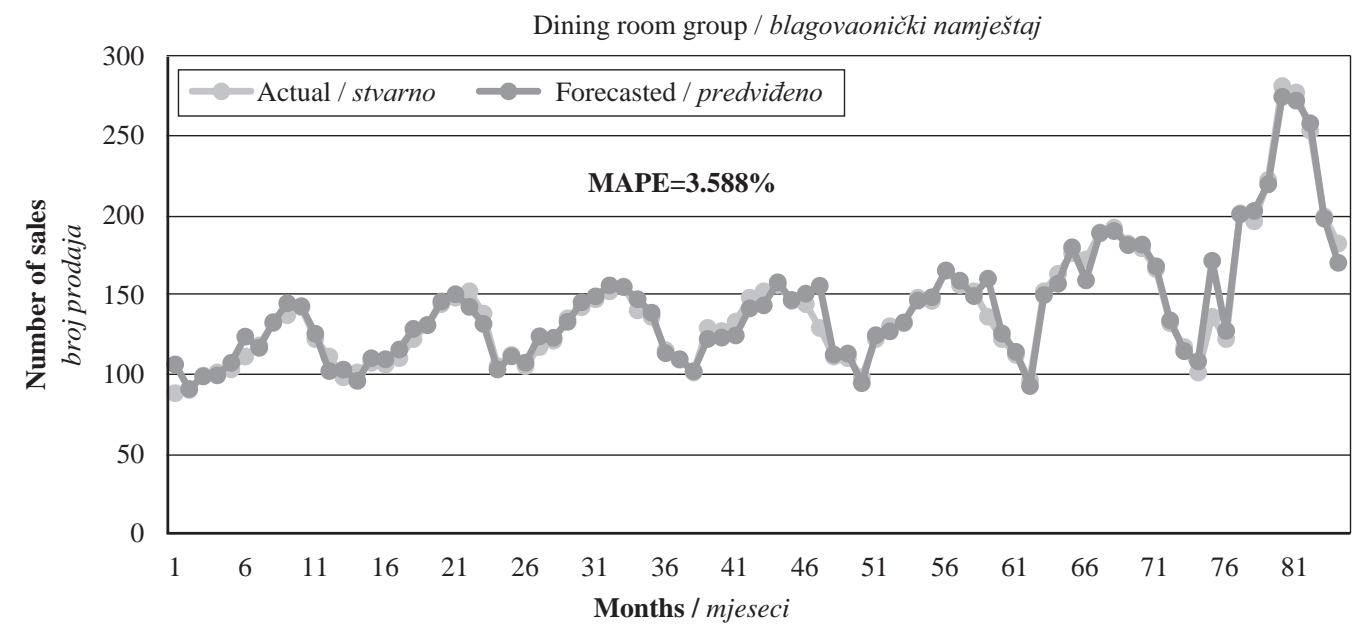

Figure 10 Comparison of actual values and forecasted output values for dining room product Slika 10. Usporedba stvarnih i predviđenih vrijednosti prodaje blagovaoničkog namještaja

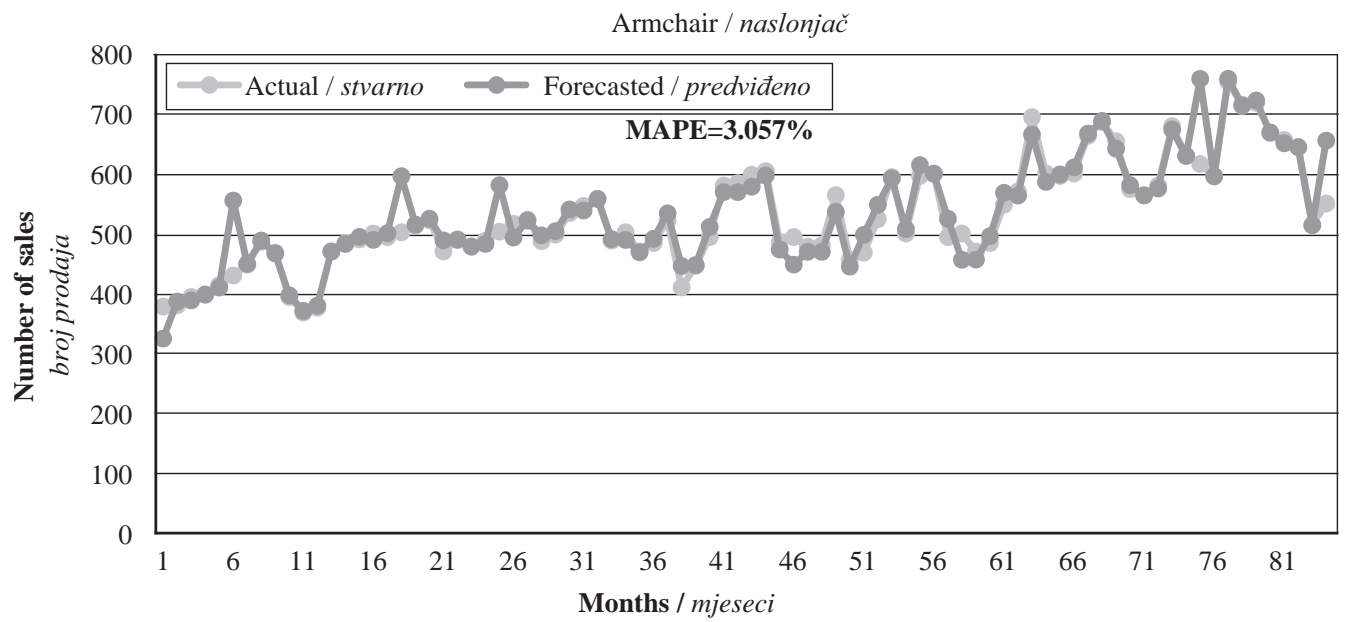

Figure 11 Comparison of actual values and forecasted output values for armchair group

Slika 11. Usporedba stvarnih i predviđenih vrijednosti prodaje naslonjača

\section{CONCLUSION}

\section{ZAKLJUČAK}

In this study, a forecasting model was developed based on Bayesian rules training in ANN to solve the problem of sales forecasting. The proposed model is applied to monthly sales of a corporate furniture manufacturing company located in the Black Sea region of Turkey. The results obtained from performance measures proved that ANN model based on Bayesian rules training is an applicable choice for forecasting monthly sales of the observed furniture factory. To the best of our knowledge, this is the first study to consider the problem.

The aim of sales forecasting is to determine the demand level of products in a particular time horizon and it is an important part of production planning. Sales forecasting is the starting point in making aggregate production planning. This part is one of the biggest problems for decision makers. Decision makers should evaluate the costs and benefits of each model before choosing an appropriate forecasting method. The ANN model was chosen because this method is easy to use, incurs low costs and offers effective solutions.
The company is local and it is much more active around the Black Sea region then other parts of Turkey. For that reason, the model can be extended with some other local parameters that influence the demand of the product such as the Black Sea region's population, number of dwellings, number of married couples and other parameters related to the Black Sea region. It should also be noted that no endogenous variables describing the company could be used, because they did not track past data properly.

In the future, the model will be further improved by considering other forecasting tools of autoregressive integrated moving average (ARIMA). From the application point of view, additional factors can be included so as to provide a more precise result, although this was not considered in the case study of the particular furniture manufacturing company.

\section{REFERENCES}

6. LITERATURA

1. Akkoyunlu, M. T.; Akkoyunlu, M. C.; Pusat, S.; Özkan, C., 2015: Prediction of accurate values for outliers in coal drying experiments. Arabian journal for science and 
engineering, 40 (9): 2721-2727. https://doi.org/10.1007/ s13369-015-1746-2.

2. Alon, I.; Qi, M.; Sadowski, R. J., 2001: Forecasting aggregate retail sales: A comparison of artificial neural networks and traditional methods. Journal of retailing and consumer services, 8 (3): 147-156. https://doi.org/10.1016/S0969-6989(00)00011-4.

3. Burden, F.; Winkler, D., 2009: Bayesian regularization of neural networks. Artificial neural networks: Methods and applications, 23-42. https://doi.org/10.1007/978-1-60327-101-1_3.

4. Çelik, Ö.; Teke, A.; Yıldırım, H. B., 2016: The optimized artificial neural network model with Levenberg-Marquardt algorithm for global solar radiation estimation in Eastern Mediterranean Region of Turkey. Journal of cleaner production, 116: 1-12. https://doi.org/10.1016/j.jclepro.2015.12.082.

5. Dogan, I.; Aydin, N., 2011: Combining Bayesian Networks and Total Cost of Ownership method for supplier selection analysis. Computers \& industrial engineering, 61 (4): 1072-1085.

https://doi.org/10.1016/j.cie.2011.06.021.

6. Efendigil, T.; Önüt, S.; Kahraman, C., 2009: A decision support system for demand forecasting with artificial neural networks and neuro-fuzzy models: A comparative analysis. Expert Systems with Applications, 36 (3): 6697-6707. https://doi.org/10.1016/j.eswa.2008.08.058.

7. Fabianová, J.; Kačmáry, P.; Molnár, V.; Michalik, P., 2016: Using a software tool in forecasting: a case study of sales forecasting taking into account data uncertainty. Open engineering, 6 (1). https://doi.org/10.1515/eng2016-0033.

8. Foresee, F. D.; Hagan, M. T., 1997: Gauss-Newton approximation to Bayesian learning. IEEE International conference on neural networks, 3: 1930-1935. https://doi.org/10.1109/ICNN.1997.614194.

9. Gahirwal, M.; Vijayalakshmi, M., 2013: Inter time series sales forecasting. arXiv preprint arXiv: 1303.0117.

10. Gul, M.; Guneri, A. F., 2016a: Planning the future of emergency departments: Forecasting ED patient arrivals by using regression and neural network models. International journal of industrial engineering: Theory, applications and practice, 23 (2): 137-154.

11. Gul, M.; Guneri, A. F., 2016b: An artificial neural network-based earthquake casualty estimation model for Istanbul city. Natural hazards, 84 (3): 2163-2178. https://doi.org/10.1007/s11069-016-2541-4.

12. Gul, M.; Guneri, A. F., 2015: Forecasting patient length of stay in an emergency department by artificial neural networks. Journal of aeronautics and space technologies (Havacilik ve uzay teknolojileri dergisi), 2 (8): 1-6. https://doi.org/10.7603/s40690-015-0015-7.

13. Guneri, A. F.; Gumus, A. T., 2008: The usage of artificial neural networks for finite capacity planning. International journal of industrial engineering: Theory, applications and practice, 15 (1): 16-25.

14. Guneri, A. F.; Gumus, A. T., 2009: Artificial neural networks for finite capacity scheduling: a comparative study. International journal of industrial engineering: Theory, applications and practice, 15 (4): 349-359.

15. Hazır, E.; Koç, K. H.; Esnaf, Ş., 2016: Türkiye mobilya satış değerlerinin örnek bir yapay zekâ uygulaması ile tahmini. Selçuk Teknik Online Dergi, 1172-1182 (In Turkish).

16. Aşarkaya, A. 2016: “Mobilya Sektörü” (online), https:// ekonomi.isbank.com.tr/UserFiles/pdf/sr05_mobilyasektoru.pdf (Accessed Dec. 15, 2016).
17. Jansen, W. J.; Nahuis, N. J., 2003: The stock market and consumer confidence: European evidence. Economics letters, 79 (1): 89-98. https://doi.org/10.1016/S0165-1765(02)00292-6.

18. Jensen, F. V., 1996: An introduction to Bayesian networks. Springer-Verlag New York, Inc. Secaucus, NY, USA.

19. Kröse, B.; Krose, B.; van der Smagt, P., 1993: An introduction to neural networks. CRC Press, London.

20. Kuo, R. J.; Wu, P.; Wang, C. P., 2002: An intelligent sales forecasting system through integration of artificial neural networks and fuzzy neural networks with fuzzy weight elimination. Neural networks, 15 (7): 909-925. https://doi.org/10.1016/S0893-6080(02)00064-3.

21. Luxhøj, J. T.; Riis, J. O.; Stensballe, B., 1996: A hybrid econometric - neural network modeling approach for sales forecasting. International Journal of Production Economics, 43 (2): 175-192. https://doi.org/10.1016/0925-5273(96)00039-4.

22. MacKay, D. J., 1992: A practical Bayesian framework for backpropagation networks. Neural computation, 4 (3): 448-472. https://doi.org/10.1162/neco.1992.4.3.448.

23. Mahbub, N.; Paul, S. K.; Azeem, A., 2013: A neural approach to product demand forecasting. International Journal of Industrial and systems engineering, 15 (1): 1-18. https://doi.org/10.1504/IJISE.2013.055508.

24. Peltzman, S., 2000: Prices rise faster than they fall. Journal of political economy, 108 (3): 466-502. https://doi.org/10.1086/262126.

25. Pusat, S.; Akkoyunlu, M. T.; Pekel, E.; Akkoyunlu, M. C.; Özkan, C.; Kara, S. S., 2016: Estimation of coal moisture content in convective drying process using ANFIS. Fuel processing technology, 147: 12-17. https://doi.org/10.1016/j.fuproc.2015.12.010.

26. Somoza, E.; Somoza, J. R., 1993: A neural-network approach to predicting admission decisions in a psychiatric emergency room. Medical decision making, 13 (4): 273280. https://doi.org/10.1177/0272989X9301300402.

27. Ticknor, J. L., 2013: A Bayesian regularized artificial neural network for stock market forecasting. Expert systems with applications, 40 (14): 5501-5506. https://doi.org/10.1016/j.eswa.2013.04.013.

28. 2013: “Türkiye mobilya ürünleri meclisi sektör raporu”, Türkiye Odalar ve Borsalar Birliği, Ankara. http://www.tobb.org.tr/Documents/yayinlar/2014/mobilya_sektor_raporu_tr_int.pdf (Accessed Dec. 12, 2016).

29. Yapıcl, F.; Esen, R.; Erkaymaz, O.; Baş, H., 2015: Modeling of compressive strength parallel to grain of heat treated scotch pine (Pinus sylvestris L.) wood by using artificial neural network. Drvna industrija, 66 (4): $347-$ 352. https://doi.org/10.5552/drind.2015.1434.

30. Yip, D. H.; Hines, E. L; Yu, W. W., 1997: Application of artificial neural networks in sales forecasting. IEEE International conference on neural networks, 4: 2121-2124. https://doi.org/10.1109/ICNN.1997.614233.

\section{Corresponding address:}

Assist. Prof. MUHAMMET GUL, Ph. D.

Munzur University, Engineering Faculty

Department of Industrial Engineering

62000 Tunceli, TURKEY

e-mail: muhammetgul@munzur.edu.tr 